INTERNATIONAL JOURNAL OF RESEARCHES IN BIOSCIENCES, AGRICULTURE \& TECHNOLOGY (C) VISHWASHANTI MULTIPURPOSE SOCIETY (Global Peace Multipurpose Society) R. No. MH-659/13(N) www.vmsindia.org

\title{
STUDIES ON INDUCED VARIATION THROUGH COLCHICINE TREATMENT IN AFRICAN WHITE MARIGOLD
}

\section{Patil S.R., Kuchanwar O.D., Deotale R.D., Jiotode D.J., Kalamkar V.B. and Rathod A.}

College of Agriculture, Nagpur Dr.P.D.K.V, Akola (M.S) India Email: shantipatil2007@rediffmail.com

\begin{abstract}
Colchicine at $0.0 \%, 0.5 \%, 1.0 \%, 1.5 \%, 2.0 \%$ and $2.5 \%$ was used for induction of variation through polyploidy in marigold by two methods viz. seed treatment and root treatment during 2016. Significant variation was observed between seed treatment method and root treatment method for all the traits studied. In seed treatment method colchiploid plants survived in all the concentration, but in root treatment method colchiploid plants survived only upto $1.5 \%$ concentration. The plants were not able to withstand the higher concentration of colchicines when roots were treated. The traits related to stomata, guard cell and pollen grain served as useful indicator for induction of variation through polyploidy. Frequency of stomata and pollen grain decreased with the increase in concentration of colchicines. On the contrary the size of stomata and guard cell in terms of length and breadth and pollen grain size on terms of diameter increased with increase in concentration. In addition treated plants were having larger and thick leaves with deep green pigmentation as compared to the untreated control. Maximum number of types of variation were recorded in $0.5 \%$ colchicine in both seed and root treatment method. Seed treatment method was found to be more efficient than root treatment method in inducing variation through polyploidy. Seeds soaked in colchicine solution at $0.5 \%$ concentration for $12 \mathrm{hrs}$ was found most effective in inducing large number of variants types. The variant plants scored on the basis of stomatal, guard cell and pollen grain traits were labeled and harvested separately for further confirmation and evaluation.
\end{abstract}

Keywords: Colchicine, seed treatment, root treatment, variation

\section{Introduction:}

Marigold (Tagetes sp.) is one of the most common grown flowers in India and used extensively on religious and social functions in different forms. Because of ease in cultivation, wide adaptability to varying soil and climatic conditions, long duration of flowering and attractively coloured, long duration of flowers endowed with excellent keeping quality, the marigolds are one of the most popular flowers in India. Due to its variable height and colour, marigold is especially used for decoration and included in landscape plants. The method of inducing polyploids in plants artificially through the application of colchicines was first demonstrated by Derman (1939) in Rhoeo. Still it is the frequently used method of increasing the chromosome number of plant. Colchicine is a poisonous chemical $\left(\mathrm{C}_{22} \mathrm{H}_{23} \mathrm{O}_{6} \mathrm{~N}\right)$ isolated from the seeds and bulbs of autumn crocus (Colchicum autumnale). It is readily soluble in water, alcohol and chloroform. Polyploidy in most cases is associated with gigantism in different plant organs like leaves, flower, fruits and stomata. In horticulture, the induction of polyploidy is a valuable route to obtain useful and novel characteristics that are not present in the diploid progenitor. These characteristics can include increased cell size (which leads to larger reproductive and vegetative organs) enhanced enzymatic activity, prolonged flowering time, no seed (or fewer seeds), as well as increased pest resistance and stress tolerance (Dhooghe et al., 2009). In this study an attempt was made to find the efficient method of inducing variation through colchicines treatment.

\section{Materials and methods:}

Two procedures were followed for treatment with colchicines such as absorption of colchicines through roots in which the seeds of diploid white marigold were sown in protray filled with potting mixture of coco pit and vermicompost. Five replication of 10 seeds for each treatment were planted in holes of protray. Then trays were kept in shade for 7 to 10 days after which the plant grew up to $6-10 \mathrm{~cm}$ height and were tagged and washed well in running water. The plants after washing were kept in the colchicines $(0.0 \%, 0.5 \%, 1.0 \%, 1.5 \%, 2.0 \%$ 
and $2.5 \%$ concentration) solution in tubes for 6 hours. After hardening these plants were transferred to the field. And in the second method absorption of colchicines was through seeds. Seeds were soaked in water for $12 \mathrm{hrs}$. followed by soaking in different concentration of colchicines $(0.0 \%$, $0.5 \%, 1.0 \%, 1.5 \%, 2.0 \%$ and $2.5 \% \mathrm{w} / \mathrm{v}$ ) for $12 \mathrm{hr}$. at room temperature $\left(25^{\circ} \mathrm{C}\right)$ for $12 \mathrm{hrs}$. Five replication of 10 seeds for each treatment were planted in the holes of protray filled with potting mixture of coco pit and vermicompost which was then gently covered with the soil. Thirty days old uniform well developed and healthy seedlings of $10-15 \mathrm{~cm}$ length were selected for transplanting.

Seedlings were transplanted in the field with a spacing of $45 \times 30 \mathrm{~cm}$ in ridges and furrow with ten plants in each row in the experimental farm of Botany Section, College of Agriculture, Nagpur during the year 2016 in five replications in CRD. Observations on stomatal frequency, stomatal length, stomatal width, guard cell length, guard cell width, pollen grain frequency and pollen grain size were recorded on each and every plant in each treatment in each replication along with survival rate and morphological variations. The data were subjected to statistical analysis by following the method described by Panse and Sukhatme (1954).

\section{Results and discussion:}

Stomatal frequency, stomatal dimension, guard cell dimension, pollen grain frequency and pollen grain size have been commonly used as the alternative method for the determination of ploidy in plants. Therefore, in this study the cytological observation on traits related to stomata, guard cell and pollen grain were recorded along with survival rate and morphological observations. The $\mathrm{F}$ test was significant for stomatal length and width, guard cell length and width, stomatal frequency, pollen grain frequency and pollen grain size in seed treatment method (Table $1 \& 2$ ). The data of root treatment were not statistically analysed as plants were not available in all the treatments. This indicates prevalence of significant variation among the treatments for these traits. Significant variation among the different colchicine treatments for the above mention cytological traits were also reported by Raghunath et al. (2014) in African marigold and Mohammad et al. (2011) in Salvia hains.

Table 1. Effect of colchicine treatment on survival rate and stomatal related traits

\begin{tabular}{|c|c|c|c|c|c|c|c|c|c|}
\hline \multirow{2}{*}{$\begin{array}{c}\text { Treatment } \\
\text { No. }\end{array}$} & \multirow{2}{*}{$\begin{array}{l}\text { Colchicine } \\
\text { concentration }\end{array}$} & \multicolumn{2}{|c|}{ Survival rate $(\%)$} & \multicolumn{2}{|c|}{ Stomatal frequency $\mathrm{mm}^{2}$} & \multicolumn{2}{|c|}{ Stomatal length $(\mu \mathrm{m})$} & \multicolumn{2}{|c|}{ Stomatal width $(\mu \mathrm{m})$} \\
\hline & & $\begin{array}{c}\text { Seed } \\
\text { treatment }\end{array}$ & $\begin{array}{c}\text { Root } \\
\text { treatment }\end{array}$ & $\begin{array}{c}\text { Seed } \\
\text { treatment }\end{array}$ & $\begin{array}{c}\text { Root } \\
\text { treatment }\end{array}$ & $\begin{array}{c}\text { Seed } \\
\text { treatment }\end{array}$ & $\begin{array}{c}\text { Root } \\
\text { treatment }\end{array}$ & $\begin{array}{c}\text { Seed } \\
\text { treatment }\end{array}$ & $\begin{array}{c}\text { Root } \\
\text { treatment }\end{array}$ \\
\hline TO & $0.0 \%$ (control) & 57.50 & 37.83 & 108.63 & 66.63 & 14.51 & 14.33 & 7.92 & 7.89 \\
\hline $\mathrm{T} 1$ & $0.5 \%$ & 35.30 & 27.27 & 79.75 & 45.56 & 20.05 & 18.64 & 15.75 & 14.98 \\
\hline $\mathrm{T} 2$ & $1.0 \%$ & 28.80 & 20.83 & 68.98 & 33.90 & 18.75 & 17.88 & 13.58 & 13.64 \\
\hline T3 & $1.5 \%$ & 11.80 & 6.00 & 56.29 & 32.66 & 17.78 & 16.75 & 10.35 & 10.42 \\
\hline $\mathrm{T} 4$ & $2.0 \%$ & 8.20 & - & 47.16 & - & 16.41 & - & 9.22 & - \\
\hline T5 & $2.5 \%$ & 6.00 & - & 42.22 & - & 15.59 & - & 9.00 & - \\
\hline \multirow{2}{*}{\multicolumn{2}{|c|}{$\begin{array}{l}\text { S.E } \pm \\
\text { C.D }\end{array}$}} & 2.04 & - & 5.24 & - & 0.90 & - & 1.22 & - \\
\hline & & 5.90 & - & 15.76 & - & 2.62 & - & 3.55 & - \\
\hline
\end{tabular}

Table 2. Effect of colchicine treatment on guard cell and pollen grain related traits and number of variant types

\begin{tabular}{|c|c|c|c|c|c|c|c|c|c|c|c|}
\hline \multirow{2}{*}{$\begin{array}{l}\text { Treatment } \\
\text { No. }\end{array}$} & \multirow{2}{*}{$\begin{array}{c}\text { Colchicine } \\
\text { concentration }\end{array}$} & \multicolumn{2}{|c|}{ Guard cell length $(\mu \mathrm{m})$} & \multicolumn{2}{|c|}{ Guard cell width $(\mu \mathrm{m})$} & \multicolumn{2}{|c|}{ Pollen frequency } & \multicolumn{2}{|c|}{ Pollen grain size $(\mu \mathrm{m})$} & \multicolumn{2}{|c|}{ No. of variant types } \\
\hline & & $\begin{array}{c}\text { Seed } \\
\text { treatment }\end{array}$ & $\begin{array}{c}\text { Root } \\
\text { treatment }\end{array}$ & $\begin{array}{c}\text { Seed } \\
\text { treatment }\end{array}$ & $\begin{array}{c}\text { Root } \\
\text { treatment }\end{array}$ & $\begin{array}{c}\text { Seed } \\
\text { treatment }\end{array}$ & $\begin{array}{c}\text { Root } \\
\text { treatment }\end{array}$ & $\begin{array}{c}\text { Seed } \\
\text { treatment }\end{array}$ & $\begin{array}{c}\text { Root } \\
\text { treatment }\end{array}$ & $\begin{array}{c}\text { Seed } \\
\text { treatment }\end{array}$ & $\begin{array}{c}\text { Root } \\
\text { treatment }\end{array}$ \\
\hline TO & $0.0 \%$ (control & 17.09 & 17.89 & 10.93 & 10.56 & 74.07 & 57.40 & 29.59 & 27.43 & - & - \\
\hline $\mathrm{T} 1$ & $0.5 \%$ & 24.09 & 24.56 & 22.64 & 22.79 & 60.22 & 46.66 & 43.17 & 34.92 & 12 & 5 \\
\hline T2 & $1.0 \%$ & 22.15 & 23.22 & 19.19 & 20.24 & 43.70 & 27.15 & 41.71 & 30.55 & 8 & 4 \\
\hline T3 & $1.5 \%$ & 20.24 & 20.49 & 16.93 & 16.66 & 39.25 & 20.44 & 34.44 & 30.31 & 7 & - \\
\hline T4 & $2.0 \%$ & 19.48 & - & 12.49 & - & 34.81 & - & 33.95 & - & 2 & - \\
\hline T5 & $2.5 \%$ & 18.08 & - & 11.56 & - & 25.18 & - & 31.41 & - & 4 & - \\
\hline & S.E \pm & 1.56 & - & 1.63 & - & 4.40 & - & 1.78 & - & - & - \\
\hline & C.D & 4.53 & - & 4.73 & - & 12.72 & - & 5.15 & - & - & - \\
\hline
\end{tabular}


Survival rate (\%) : Highest survival rate was observed in control (57.5\%) followed by $0.5 \%$ colchicine treatment (35.3\%) and $1 \%$ colchicine $(28.8 \%)$. The least survival \% was observed in $2.5 \%$ colchicine $(6 \%)$ in seed treatment method. Similarly survival rate was maximum in control $(37.83 \%)$, followed by $0.5 \%$ colchicines $(27.27 \%)$ and $1.0 \%$ colchicines $(20.83 \%)$ in root treatment method. The results indicated that increase in the concentration leads to decrease in survival rate in both the method of treatment. But in root treatment the colchiploid plants were not able to survive in 2.0 and $2.5 \%$ colchicines. These findings were in consistent with the finding of Jiranapapan et al. (2011) in Torenia fournieri, Mohammad et al. (2011) in Salvia hains and Liu et al. (2007) in Platanus acerifolia who reported that the survival rate of colchicine treated shoots were lower, with the extent of the reduction depending on the colchicine concentration. Decrease in survival rate with increase in concentration of colchicine may be due to the cause of tissue necrosis when soaked in different concentration of colchicine solution. This is because colchicine does not only have an effect on cell division but spreads through the cell, interfering with cellular mechanism and causing toxicity at high concentration as reported by Sasiree et al. (2013). Colchicine apparently affect the viscosity of cytoplasm so the cell cannot function normally.

Traits related to stomata: The effect of colchicine on stomatal frequency were higher in colchiploid plants and tends to be low than that of untreated plants both in seed and root treatments. Stomatal frequency was highest in control in both the method and this was followed by $0.5 \%$ colchicine and $1 \%$ colchicines. It is observed that increase in concentration of colchicine have decreased stomatal frequency. In both the method of colchicines treatment $0.5 \%$ colchicine showed maximum stomatal length followed by $1 \%$ colchicine. Maximum width of stomata was observed in $0.5 \%$ colchicine followed by $1 \%$ colchicines in both the method. The data related to stomatal traits revealed that untreated control exhibited maximum stomatal frequency and least stomatal length and in both the method of cochicine treatment. Colchicine treatment has decreased the stomatal frequency and increased the stomatal length and width. This reveals that variation in the stomatal traits due to colchicine treatments acts as an indicator for the variation induced through colchiploidy. Similar to this result Raghunath et al. (2014) observed lower frequency of stomata from the leaves of $5 \mathrm{ppm}$ colchicine treated plant than the leaves of untreated control. They also reported that the stomatal dimension (length and breadth) of colchicine treated plant appeared to be greater than the untreated control in African marigold.

Guard cell length and width $(\boldsymbol{\mu m})$ : Like stomatal trait guard cell dimension is also closely connected with the induction of polyploidy. In both the method $0.5 \%$ colchicine showed maximum guard cell length followed by $1 \%$ colchicine. Maximum width of guard cell was observed in $0.5 \%$ colchicine at in both the method of colchicine treatment and was followed by 1 $\%$ colchicine. The results on guard cell length and width measured in two methods of seed treatment revealed that colchicine treatment have increased the size of guard cell in terms of both length and width. Increase in size was observed to be more at lower concentration of colchicine as compared to higher concentration. In accordance to this study Dario and Paul (2009) reported that guard cell length increased and were larger in colchicine treated plants in Vaccininium darrowii and hence were an efficient way to screen for colchiploid changes after colchicine treatment. Increase in stomatal guard cell length with doubled ploidy level has also been observed in African marigold by Raghunath et al. (2014).

Pollen grain traits: The effect of colchicine on pollen grain frequency were higher in colchiploid plants and tends to be low than that of untreated plants. Frequency was highest in control $(74.07 \%)$ followed by 0.5 $\%$ colchicine $(60.22 \%)$ in seed treatment method and the treatment $2.5 \%$ colchicine $(25.18 \%)$ showed minimum pollen grain frequency. In root treatment method pollen 
frequency was highest in control (57.40\%) followed by $0.5 \%$ colchicine

146.66

$\%)$ and the treatment $1.5 \%$ colchicine $(20.44 \%)$ showed minimum pollen grain frequency. It is observed that increase in concentration of colchicine have decreased pollen grain frequency in the descending manner. The treatment $0.5 \%$ and $1 \%$ colchicine showed maximum size of pollen grain in both the method of treatment. Colchicine treatment were found to increase the size of pollen grain. The results on pollen traits revealed that colchicine treatment have decreased the pollen grain frequency and increased the pollen grain size. In consistent to this observation Dario and Paul (2009) in Vaccinium darrowii reported that pollen diameter were larger in some colchicine treated plants and guard cell length along with pollen diameter measurement were an efficient way to screen for polyploidy changes after colchicine treatment, Mohammad et al. (2011) also reported larger pollen size in colchiploid plants in Salvia hains.

Morphological observation: The aim of this research work was also to induce variation through colchicine treatment and select some useful variant which can be stabilised and used for developing new variety. Major morphological and growth habit characteristics observed in seedlings or plants treated with colchicine showed reduced stem elongation, growth and slower node development, relative to control seedlings, and in some cases, the first 1-2 true leaves were morphologically abnormal eg. wrinkled, subsequent leaves appeared normal. These effects on seedling growth were most evident at the higher colchicine concentrations (1.5 to $2.5 \%$ ). In consistent with this results Liu et al. (2007) also reported morphological differences of the colchiploid plants which included a more compact growth habit, broader and thicker leaves in marigold. Maximum number of variants of 12 types were observed in the treatment of $0.5 \%$ colchicine followed by 1 $\%$ colchicines recording 8 types of variant (Table 2) . Least number of variants were recorded in $2.0 \%$ colchicine (2 variant types) followed by $2.5 \%$ colchicines (4 variant types) in seed treatment method.
But in root treatment method variant types were obtained only in 0.5 and $1.0 \%$ colchicines treatment recording 5 and 4 variant types respectively. All the variants identified were labeled and harvested separately. The results on morphological observation reveals that $0.5 \%$ colchicine for $12 \mathrm{hrs}$. is more effective in inducing variation followed by $1 \%$ colchicine for 12 hrs in seed treatment method. In consistent to this result Kazi (2013) observed maximum variation with $0.2 \%$ and $0.3 \%$ colchicine for $12 \mathrm{hrs}$ in Marigold.

\section{Conclusion:}

It is concluded from this study that seed treatment method is more efficient than root treatment method. The optimum concentration of colchicine to induce variation is $0.5 \%$. The colchiploid treated marigold plants scored on the basis of stomatal, guard cell and pollen grain traits requires to be confirmed from further cytological studies.

\section{References:}

Dario, J. C. and M. L. Paul. 2009. Production and identification of colchicinederived tetraploid Vaccinium darrowii and its use inbreeding. J. Amer. Soc. Hort. Sci. 134(3): 356-363.

Derman, H. 1938. A cytological analysis of polyploidy induced by colchicines and by extreames of temperature. J. Hered. 29:211214.

Dhooghe, E., w. Grunewald, L. Leus. and M. C. Van Labeke. 2009. In Vitro polyploidisation of Helleborus species. Euphytica, 165 : 89-95.

Dunstone, R.L., R.M.Gifford, and L.T.Evans, 1973. Photoxynthetic characteristics of modern and primitive wheat species in relation to ontogeny and adaptation to light. Aust. J. Biol.Sci. 26:295-307.

Jiranapapan, J., S.Kikuchi, B. Manochai, T. Taychasinpitak, H. Tanaka and $H$. Tsujimoto, 2011. A simple method chromosome doubling using colchicines in Torenia (Linderniaceae), and the behavior of meiotic chromosome in amphidiploids. Chromosome Sci. 14: 29-32.

Kazi, N.A. 2013. Effect of colchicine on growth and flowering of China aster 
(Callistephus chinensis Nees.). Eco. Env. \& Cons. 19 (1): 83-86.

Liu, G. 2007. Colchicine-induced chromosome doubling in platanus acerifolia and its effect on plant morphology. Euphytica. 157: 145-154

Mohammad, S. H. G. H. Meftahizade, N. Lotfi, V. Rahimiand B. Baniasadi. 2011. Doubling the chromosome number of Salvia hains using colchicine: evaluation of morphological traits of recovered plants. J. Medi. Plants Res. 5 (19): 4892-4898.

Panse, V. G. and P. V. Sukhatme. 1954. Statistical method for agriculture worker. I.C.A.R. publications, New Delhi. 2nd edn. PP 63-66.
Raghunath, S. A.Ganguly, P.K.Singh and H.K.Sarkar, 2014. Study of induced polyploidy in African Marigold (Tagetes erecta L.). Environment \& Ecology, 32(4): 1219-1222.

Sasiree, B, T. Taychasinpitak, S. Wongchaochant and S.Kikuchi, 2013. Effect of colchicines tablets on morphology of Torenia fournieri, Int. Transaction J. of Engg. Management \& Applied Sci. \& Tech., 4:299-309. 